\title{
An Application of Generalized Moments Method to Examine the Management Behavior during Peak Season A Study in Islamic Micro Finance Industry
}

\author{
Yayat Nurhidayat ${ }^{1, *}$ \\ Applied Master of Islamic Banking and Finance, Politeknik Negeri Bandung, Indonesia
}

\begin{abstract}
In the current highly competitive finance industry, it is important that any financial institution to develop a proper strategy to compete in the market. More specifically, the finance managers need to have an appropriate liquidity and stability strategy during the peak season where their customers have a high demand of cash. Finding such a strategy is challenging for micro finance institution due to their limited resources, in terms of finance and human resources. This study is aimed to (1) analyze the impact of liquidity risk to the stability of micro finance institutions and to (2) assess the relationship between liquidity risk and credit risk in the period of peak season by using Generalized Moments Method. The focus of this study is Islamic micro finance institutions in West Java for the period 2012-2017. Using monthly data, this study reveals that the risk of liquidity has a negative effect on the level of stability of micro finance institutions at peak season and has a positive influence on the level of stability at off peak season. Further, the study finds that the relationship between liquidity risk and credit risk is significant during the period of peak season and off peak season period. Therefore, it can be concluded that in general credit risk impacts on liquidity risk. The findings of this study provide significant contributions in terms of enlarging our understanding on the management behavior related to institution liquidity and stability during the peak and non-peak season. From managerial perspective, this study helps the Islamic micro finance institution to remain stable and competitive during the peak season.
\end{abstract}

\section{Introduction}

In terms of the collection of third party funds or obligations and capital sourced from low income communities, the Islamic Micro Finance Institution (IMFI) has a high risk. Therefore, the probability of supply of third party funds originating from deposits and saving will have a high risk of fluctuating income. the reason for the high risk of lowincome people to third-party fund collection is illiquidity with income fluctuations and informal money-storage mechanisms [1] [2]. Such as storing cash in the house, buying and

\footnotetext{
${ }^{a}$ Corresponding author: ya_nur81@yahoo.com
} 
selling farm and agricultural goods that are not durable. In particular, Zeller and Sharma [3] suggest that IMFI have difficulties in diversifying their portfolios because farmers have income that depends on the harvest period. Therefore, IMFI will have risks from two sides, namely in terms of IMFI assets and in terms of obligations and capital of IMFI. Therefore, IMFI has a vital role in maintaining its stability so that liquidity mismatches and negative balance conditions do not occur because of the collection and financing of funds to "unsecured creditor"

IMFI liquidity can be well maintained at the level of "health" if the IMFI can carry out its two main functions of creating liquidity and transforming risk [4]. These two functions are often referred to as qualitative asset transformation functions [5]. IMFI can create liquidity both on the balance sheet (on balance sheet) and off balance sheet. At the same time, IMFI creates liquidity through financing assets that are relatively less liquid with relatively liquid debt [6]. Likewise on off balance sheet, IMFI can make financing commitments and claims on liquid funds [7]. In fact, the existence of a IMFI financing commitment can provide a mechanism to optimally share risk, reduce financing rationalization, and reduce the impact of information friction between debtors and IMFI [8]. The second function, namely risk transformation, is carried out by IMFI in line with the implementation of the liquidity creation function, among its forms, namely that IMFI issues time and savings (DPK) savings products at low risk to fund risky financing. Although the relationship is not perfect, the amount of liquidity that has been created will be positively correlated to the level of risk being transformed. Therefore, the level of risk on liquidity will also affect the level of stability of the IMFI itself.

In Indonesia, the level of risk to liquidity is strongly influenced by the pattern or habit of the community in a certain period which has become a culture for many years and generations, the habit is a consumptive pattern in the Peak Season period. The term Peak Season can be foreign in the eyes of the world, but in Indonesia this phenomenon is real and has succeeded in making some financial institutions unstable. Peak season is a site that is not much different from high season. However, peak season is much more crowded and crowded than high season. In the world of Peak traveling, Season is often identified with the peak period of the holiday season. Peak Season in this case is the peak period where people flock to attract savings / savings for seasonal consumption purposes, namely the Iedul Fitr session and the session to attend children's school. This period is expected to cause IMFI to be vulnerable to financial distress or unstable. Based on the assumptions and results obtained from previous findings, this paper has more value by combining the previous assumptions in the Peak Season period. This is because the results found by Elgari [8] indicate the stability and resilience of IMFI in the long run if due to high growth compared to conventional financial institutions, while according to Sulung and Wahyudi [9] Liquidity risk significantly affects the IMFI stability level.

Therefore, researchers want to examine more about the creation of liquidity by IMFI in the Peak Season period and try to answer the following questions about the relationship between liquidity risk and the level of stability in the IMFI and the relationship between liquidity risk and credit risk in influencing the stability of the IMFI. Then, in Part 2 will be discussed about literature review, Section 3, will discuss the research methodology, Section 4, will discuss the results and analysis, and Section 5, will discuss the conclusions of the research questions discussed in Chapter 1.

\section{Literature}

The fundamental function of the IMFI is to channel funds from those who have excess funds to those who need funds. Specifically, the excess funds collected by the IMFI from depositors, and the rest are called third party funds (TPF), in the form of savings-based 
contract savings, both wadiah yad amanah (pure deposit) and wadiah yad dhamanah (deposit in the form of debt), as well as deposits. Futures such as deposits with the basis of the mudaraba syirkah contract. Then, the TPF that has been collected will be channeled back to the community in the form of a financing contract. In general, the financing agreements commonly used by IMFI can now be grouped into two groups, namely debtbased contracts and syirkah-based contracts. Debt agreements are divided into two groups, namely pure debt (qardhul hasan) and debt arising from buying and selling activities (buying and selling greetings and muajjal). The syirkah contract commonly used is mudharabah, musyarakah, musaqat and muzara'ah. The last two contracts are only used for the agricultural and plantation sectors.

Like financial industry products from other financial institutions, Islamic financial products will also be affected by credit and liquidity risks. Liquidity risk occurs because of the difficulty in selling assets quickly without suffering a lot of losses [10]. Liquidity risk is defined as a maturity mismatch between assets and liabilities at an unsynchronized time between cash in and cash out of business [11]. As for the sharia concept, we will also add "forms of sale and purchase contracts", and "sharia restrictions on the sale of debt" into the liquidity risk variable in the case of IMFI.

\subsection{Effect of Liquidity Risk on the Stability Level of IMFI}

Related to the relationship between liquidity risk and the level of stability of IMFI. Some findings from Bryant [6], Diamond and Dybvig [12], and Berger and Bouwman [4] say that liquidity risk will affect the stability of the IMFI can be measured among others by Z-score, non-performing loan, and others. Based on the assumptions and results obtained from previous findings, this paper has more value by combining the previous assumptions in the Peak Season period, therefore, our hypothesis is related to the relationship between liquidity risk and the stability level of the IMFI, namely:

H1: Liquidity risk has a negative influence on the level of stability in the IMFI $S$ in the peak season period.

\subsection{Reciprocal Relationship between Liquidity Risk and Credit Risk in Affecting the Stability of IMFI}

Other factors that affect the level of stability of the IMFI and have a relationship with liquidity risk are the level of credit risk. The classical theory of microeconomics says that there is a close relationship between liquidity risk and credit. The Monti- Klein Framework, Bryant [6] or Diamond and Dybvig [12] state that the structure of assets and debt will relate, more specifically to bad credit and withdrawal of funds by customers [13]. This does not only occur in the IMFI balance sheet but also on financing and business funding especially on off-balance sheets. Based on this, the relationship between liquidity risk and credit will also affect the level of stability of the IMFI. Several papers that show both of these risks have an influence on the level of stability of IMFI, namely Goldstein and Pauzner [14], Acharya and Viswanathan [15] and Acharya and Mora [16].

Based on the assumptions and results obtained from previous findings, this paper has more value by combining the previous assumptions in the Peak Season period, therefore, our hypothesis is related to the relationship between liquidity risk and the stability level of the IMFI, namely:

H2: Credit risk has a positive influence on liquidity risk in IMFI

H3: Liquidity risk has a positive influence on credit risk in IMFI 


\section{Method}

The sample used in the study amounted to 4 IMFI in West Java. Each sample has 5 years for the period 2013 to 2017. This study uses secondary data IMFI financial statements needed consisting of balance sheet reports, income statements, and financial ratio reports. All financial report data were obtained through the Sharia Cooperative Center (SCC). Answer. The explanation of the variables used in this study is explained in Table 1 Operationalization of Research Variables. The methodology used in this study uses the Fixed Effect Data on testing the effect of liquidity risk on the stability of the IMFI. Then, we also use the Generalized Moments Method (GMM) to test the reciprocal relationship between liquidity risk and credit in influencing the stability level of the IMFI.

Table 1. Operationalization of research variables

\begin{tabular}{|l|l|}
\hline $\begin{array}{c}\text { Type of dependent } \\
\text { variable }\end{array}$ & \multicolumn{1}{c|}{ Description } \\
\hline Z-Score & $\begin{array}{l}\text { The ratio of Return on Assets (ROA) plus the equity to asset } \\
\text { ratio (CAR) is divided by the standard deviation of ROA } \\
\text { (SDROA) }\end{array}$ \\
\hline Free & \\
\hline $\begin{array}{l}\text { Liquidity Risk (LR) it- } \\
1\end{array}$ & $\begin{array}{l}\text { ([Immediate obligations + Wadiah savings + Other liabilities + } \\
\text { Financing received] - [Cash] + Placement with other Banks) } \\
\text { Total assets }\end{array}$ \\
\hline Credit Risk (CR)it-1 & NPF Ratio \\
\hline Control & Profit (loss) ratio to total assets \\
\hline ROA & Profit (loss) to total equity ratio \\
\hline ROE & Total credit ratio to total assets \\
\hline LOAN TO ASSET & $\begin{array}{l}\text { Peak period Savings collection is taking above average in one } \\
\text { year which is indicated by number 1 if there is peak season and } \\
0 \text { if it does not occur }\end{array}$ \\
\hline PEAK SEASON & \\
\hline
\end{tabular}

The dependent variable in this study is the risk of IMFI where the Z-score is used as the main indicator in measuring risk. The $\mathrm{Z}$-score is defined as how much the standard deviation of return on assets of an IMFI must fall to make the IMFI become insolvent [16]. The higher the value of the z-score shows that the IMFI has a lower risk and tends to be stable, whereas the lower the value of the z-score indicates that the IMFI faces higher risks and tends to be unstable.

Variables for liquidity risk (LR) are calculated by subtracting all assets that can be quickly changed in cash to cover withdrawals from short-term liabilities. We do not use derivatives and securities because they do not appear in the balance sheet report of IMFI and not the main business of the IMFI. Then for other independent and reciprocal variables, credit risk is calculated from the ratio of non-performing financing (NPF) to calculate the value of credit risk.

\subsection{Research Hypothesis}

Some findings from Bryant [6], Diamond and Dybvig [12], Diamond and Rajan [11], and Berger and Bouwman [4] say that liquidity risk will affect the stability of IMFI. Based on this explanation, the following is the research hypothesis related to the effect of non-interest income on the z-score:

$\mathbf{H}_{\mathbf{1}}$ : Liquidity risk has a negative influence on the level of stability in the IMFI in the peak 
season period.

Where the higher the value of z-score indicates that the IMFI has a lower risk and tends to be stable, on the contrary the lower the value of the z-score indicates that the IMFI faces a higher risk and tends to be unstable.

\subsection{Research Model}

Goldstein and Pauzner [14], Acharya and Viswanathan [15] and Acharya and Mora [16] show the relationship between liquidity risk and credit in influencing the stability of IMFI. Therefore, the reciprocal hypothesis which states the relationship between the two risks is as follows:

$\mathbf{H}_{2}$ : Credit risk has a positive influence on liquidity risk in influencing the level of stability of IMFI.

$\mathbf{H}_{\mathbf{3}}$ : Liquidity risk has a positive influence on credit risk in influencing the level of stability of IMFI.

\section{Result}

Based on the results of the IMFI from 2012 to 2017, descriptive statistics on the Z-score showed an average score of 6.08 with a maximum value of 16.26 and a minimum value of 3.10 . As for liquidity risk with an average value of 1.47 with a maximum value of 2.34 and a minimum value of 0.22 .

Table 2. Descriptive Statistic

\begin{tabular}{|l|r|r|r|r|}
\hline & \multicolumn{1}{|c|}{ Mean } & \multicolumn{1}{c|}{ Max } & \multicolumn{1}{c|}{ Min } & \multicolumn{1}{l|}{ SDev } \\
\hline Z-Score & 6.08212 & 16.26502 & 3.10780 & 2.46218 \\
\hline LR & 1.47635 & 2.34520 & 0.22029 & 0.49941 \\
\hline CR & 0.03694 & 0.05326 & 0.03015 & 0.00492 \\
\hline ROA & 0.00925 & 0.05739 & $(0.02844)$ & 0.01497 \\
\hline ROE & 0,01310 & 0,54763 & $(0.82985)$ & 0,15516 \\
\hline $\begin{array}{l}\text { Loan to } \\
\text { Asset }\end{array}$ & 0,41825 & 0,67738 & 0,23591 & 0,08546 \\
\hline $\begin{array}{c}\text { Peak } \\
\text { Season }\end{array}$ & 0.30000 & 1.00000 & - & 0.46212 \\
\hline
\end{tabular}

The value for liquidity risk is so large because in current assets this value depends only on cash and placements with other IMFI or BANKS. As for the value of credit risk, the average value of this risk is $3.69 \%$ with a maximum value of $5.32 \%$. This value is a reasonable value.

\subsubsection{Effect of Liquidity Risk on the Stability Level of IMFI}

To see the influence of liquidity risk on the stability level of IMFI, this study uses panel data with a fixed effect model for each model from model 1 to 3 . Each model uses the Zscore variable per month to see the changes in each period. As for the independent variables, we use existing variations, either only by using liquidity risk variables, or only credit risk variables, or interactions between the two risks. In addition, we also use several control variables including return on equity, return on assets, and loan to assets and peak season. We process data using a single risk (liquidity and credit) in model 1 while models 2 
and 3 are to see a combination of all the independent variables and control variables that exist.

Table 3. Effects of Liquidity and Credit Risk on the Stability Level of IMFI

\begin{tabular}{|l|c|c|c|}
\hline & 1 & 2 & 3 \\
\hline LR & 0,31367 & $-0,973973$ & $-0,230735$ \\
\hline CR & $-0,89162$ & $-0,291031$ & $-0,342701$ \\
\hline LOAN TO & & & \\
ASSET & & $-2,552251$ & $-4,595383$ \\
\hline ROA & & & 6,212034 \\
\hline ROE & & & $-3,422416$ \\
\hline PEAKSESON & & $-0,794571$ & $-0,620559$ \\
\hline Adj R-Square & 0,121633 & $-0,252466$ & 0,218814 \\
\hline J-Statistic & 0,00000 & 0,089137 & 0,932345 \\
\hline
\end{tabular}

Based on Table 3, the value on liquidity risk shows a positive value in model one and shows a negative value on models two and three. According to Sulung LAK, Wahyudi, I [17] the higher the liquidity risk (LR) shows the lower z-score value, indicating that the more unstable the IMFI is, the lower the value of liquidity risk, the higher the z-score given, this indicates a high $\mathrm{z}$-score tends to be more stable for financial institutions. Therefore, there is an inverse relationship between liquidity risk and the stability of the IMFI. With a confidence level of $99 \%$, it can be said that liquidity risk in the peak season period has a significant negative influence on the level of IMFI stability measured from the z-score but not in the non-peak season period.

The negative relationship between liquidity risk and stability of IMFI needs to get more serious attention from several interested parties because the average liquidity risk value of IMFI is $147.63 \%$ with the highest value of $234.52 \%$ based on the results of descriptive statistics (see Table 2). This further strengthens the results of research conducted by Wahyudi, I (2015) where the average value of liquidity risk reached $50.52 \%$ with the highest value of $182 \%$. Strengthening the results of this previous study is because in this study, researchers included elements of the peak season period as a control variable so that it strengthens that liquidity risk must be a focus and needs attention from certain parties, especially Islamic microfinance institutions whose notes move in low-income societies. Who are susceptible to peak season so that cash and placements with other banks cannot finance their current liabilities.

The effect of significant Liquidity and Peak Risks on the stability of the IMFI is seen consistently from model 2 and model 3 . This indicates that the reliability of the results obtained from the influence of the risk of liquidity and stability of the IMFI can be accounted for.

\subsubsection{Relationship between Liquidity Risk and Credit Risk}

Based on Table 4, the significant effects of pool and random effects for the GMM model can be seen from the effect of credit risk on both liquidity risk for the alpha level of $1 \%, 5 \%$ and $10 \%$. Then the effect of liquidity risk on credit can only be seen in the pool effect of GMM only for the 3rd lag. Therefore, it can be concluded that there is no general effect of credit risk on liquidity risk. 
Table 4. Relationship between Liquidity Risk and Credit Risk

\begin{tabular}{|l|r|r|r|r|r|}
\hline & \multicolumn{2}{|c|}{$\begin{array}{c}\text { Dependent } \\
\text { Variable=LR }\end{array}$} & & \multicolumn{2}{c|}{$\begin{array}{r}\text { Dependent Variable } \\
=\text { CR }\end{array}$} \\
\hline & \multicolumn{1}{|c|}{ Pool } & \multicolumn{1}{|c|}{ Random } & & \multicolumn{1}{c|}{ Pool } & \multicolumn{1}{c|}{ Random } \\
\hline C & $-1,0266$ & $-1,0266$ & C & $-0,0339$ & $-0,1361$ \\
\hline CR(-1) & $-0,1874$ & $-0,1874$ & CR(-1) & 0,7648 & 0,4718 \\
\hline CR(-2) & 0,2851 & 0,2851 & CR(-2) & $-1,0594$ & $-0,2676$ \\
\hline CR(-3) & 0,1466 & 0,1466 & CR(-3) & 1,0967 & 0,6859 \\
\hline LR(-1) & 0,3718 & 0,3718 & LR(-1) & $-0,0574$ & $-0,1184$ \\
\hline LR(-2) & $-0,0353$ & $-0,0353$ & LR(-2) & $-0,0201$ & 0,0059 \\
\hline LR(-3) & 0,2194 & 0,2194 & LR(-3) & 0,0020 & 0,1589 \\
\hline & & & & & \\
\hline Adjusted R-Squared & 0,6887 & & & 0,2362 & 0,1204 \\
\hline J-Statistic & 54,9893 & & & 16,0749 & 14.3982 \\
\hline
\end{tabular}

\section{Conclusion}

The results of this study have positive implications for liquidity management in Islamic microfinance institutions. Based on the results obtained, liquidity risk significantly affects the stability of an IMFI during the peak season period in all models combined [18]. This implies that the results obtained can be accounted for because of consistency. Consistency in this case is that every model added with peak season variable has an average value of IMFI liquidity risk that is not so good value. Therefore, this needs to be considered by the stakeholders because it will affect the level of stability of the IMFI which will ultimately affect the financing of low-income people [19] [20]. Then, the relationship between liquidity risk and credit shows insignificant results in the reciprocal relationship between the two because credit risk has a significant effect on liquidity risk at a certain level of significance but not the opposite on liquidity risk to affect credit risk. For future research, it is necessary to investigate further about what factors affecting the Indonesian community attract saving at IMFI during peak season period.

\section{Reference}

1. Collins D, Morduch J, Rutherford S, Ruthven O. Portfolios of the poor: how the world's poor live on \$2 a day: Princeton University Press; (2010).

2. Dupas P, Robinson JJAER. Why don't the poor save more? Evidence from health savings experiments. 2013;103(4):1138-71.

3. Zeller M, Sharma M. Rural finance and poverty alleviation. International Food Policy Research Institute (IFPRI), (1998).

4. Berger AN, Bouwman CHJTrofs. Bank liquidity creation. 2009;22(9):p.3779-837.

5. Bhattacharya S, Thakor AVJJofI. Contemporary banking theory. 1993;3(1):p.2-50.

6. Bryant JJJob, finance. A model of reserves, bank runs, and deposit insurance. 1980;4(4):335-44.

7. Holmström B, Tirole JJJoPE. Public and private supply of liquidity. 1998;106(1):p.140.

8. Elgari MA. Credit risk in Islamic banking and finance. (2003).

9. Wahyudi I, Sulung L. Mengkaji Perilaku Manajemen Likuiditas Pada Bank Perkreditan Rakyat Syariah di Indonesia. (2015). 
10. Ali SS. State of liquidity management in Islamic financial institutions. (2013).

11. Diamond DW, Rajan RGJJopE. Liquidity risk, liquidity creation, and financial fragility: A theory of banking. 2001;109(2):p.287-327.

12. Diamond DW, Dybvig PHJJope. Bank runs, deposit insurance, and liquidity. 1983;91(3): 401-19.

13. Suhartanto D, Dean D, Nansuri R, Triyuni NJJoBR. The link between tourism involvement and service performance: Evidence from frontline retail employees. 2018;83:130-7.

14. Goldstein I, Pauzner AJtJoF. Demand-deposit contracts and the probability of bank runs. 2005;60(3):1293-327.

15. Acharya VV, Viswanathan SJTJoF. Leverage, moral hazard, and liquidity. 2011;66(1):99-138.

16. Acharya VV, Mora NJTjoF. A crisis of banks as liquidity providers. 2015;70(1):1-43.

17. Sulung LAK, Wahyudi IJJKdP. Mengkaji Perilaku Manajemen Likuiditas Pada Bank Perkreditan Rakyat Syariah Di Indonesia. 2017;17(2).

18. Demirgüç-Kunt A, Huizinga HJJoFE. Bank activity and funding strategies: The impact on risk and returns. 2010;98(3):626-50.

19. Wahyudi I, Dewi MK, Rosmanita F, Prasetyo MB, Putri NIS, Haidir BM. Manajemen Risiko pada Perbankan Islam: Konsep dan Praktek di Indonesia. . Jakarta: Salemba Empat; (2013).

20. Suhartanto DJIJoTP. The role of store coopetition and attractiveness on the performance of tourism destination and its retail stores. 2017;7(2):151-65. 